\title{
KONTROL KECEPATAN MOTOR INDUKSI TIGA FASA MELALUI ARUS ROTOR MENGGUNAKAN PI
}

\author{
Adlio Dwismara E \\ Program Studi Teknik Elektro, \\ Fakultas Teknik dan Ilmu Kelautan, \\ Universitas Hang Tuah, \\ Surabaya \\ adlioe52@gmail.com
}

\author{
Geral Junio R \\ Program Studi Teknik Elektro, \\ Fakultas Teknik dan Ilmu Kelautan. \\ Universitas Hang Tuah, \\ Surabaya \\ geraljunio12@gmail.com
}

Moch Toriq Setiawan Program Studi Teknik Elektro, Fakultas Teknik dan Ilmu Kelautan, Universitas Hang Tuah, Surabaya muhammadtoriksetiawan@gmail.com

\begin{abstract}
Dalam makalah ini disajikan pengaturan kecepatan motor induksi tiga fasa dalam bentuk simulasi. Pengaturan kecepatan motor dilakukan dengan menghubungkan resistor luar tiga fasa pada slip-ring rotornya. Arus bolak balik dari slip-ring rotor motor kemudian disearahkan oleh penyearah tiga fasa dan dihubungkan pada $D C-D C$ konverter. Pensaklaran DC-DC konverter menggunakan metode Zero Voltage Switching (ZVS). Proses pensaklaran tegangan tegangan nol sewaktu turn-on dengan bantuan komponen induktor resonansi $L_{r}$ dan kapasitor resonansi $\mathrm{C}_{\mathrm{r}}$. Penelitian ini bertujuan merancang suatu DCDC konverter dengan sumber tegangan dari terminal rotor pada motor induksi tiga fasa. DC-DC konverter yang dirancang menggunakan mode pensaklaran zero voltage switching (ZVS) dengan komponen induktor dan kapasitor yang diparalel. Berdasarkan hasil pengukuran pengaturan arus rotor induksi tiga fasa dengan metode ZVS dapat mengubah kecepatan rotor pada motor induksi tiga fasa pada rotor lilit tersebut.
\end{abstract}

Kata Kunci- induksi, DC-DC konverter, Zero Voltage Switching, tiga fasa

\section{Pendahuluan}

Motor induksi tiga fasa merupakan motor arus bolak-balik yang paling banyak digunakan sebagai aktuator yang mengubah energi listrik menjadi energi gerak untuk berbagai keperluan dalam proses produksi pada suatu industri. Konstruksinya yang sederhana dan kuat mendasari alasan keluasan pemakaianya. Namun motor induksi 3 fasa tidak terlepas dari beberapa kekurangan seperti arus start yang besar dan nilai overshoot motor yang mempengaruhi performa motor induksi tersebut. Salah satu pengatur kecepatan pada motor induksi rotor belitan tiga fasa yakni menghubungkan resistor luar tiga fasa pada slip-ring rotornya. Cara ini akan didapatkan torsi awal yang tinggi dan arus awal yang rendah. Tetapi cara ini tidak efisien bila terjadi ketidakseimbangan tegangan dan arus karena resistansi tiap fasanya tidak seimbang. Untuk hal tersebut, resistor tiga fasa ini dapat digantikan dengan satu resistor yang bernilai tetap. Daya dari slip motor kemudian di searahkan oleh penyearah tiga fasa yang dihubungkan ke Dc-Dc konverter dengan pensaklaran. Pensaklaran DC-DC konverter menggunakan metode Zero Voltage Switching (ZVS). Proses pensaklaran tegangan tegangan nol sewaktu turn-on dengan bantuan komponen induktor resonansi $\mathrm{L}_{\mathrm{r}}$ dan kapasitor resonansi $\mathrm{C}_{\mathrm{r} .}$.

\section{BAHAN DAN METODE}

Metode modul penelitian ZVS buck konverter dengan motor induksi tiga fase terdiri dari dua blok rangkaian, yaitu blok rangkaian kontrol dan blok aliran rangkaian daya. Berikut adalah gambar blok diagram metode tersebut.

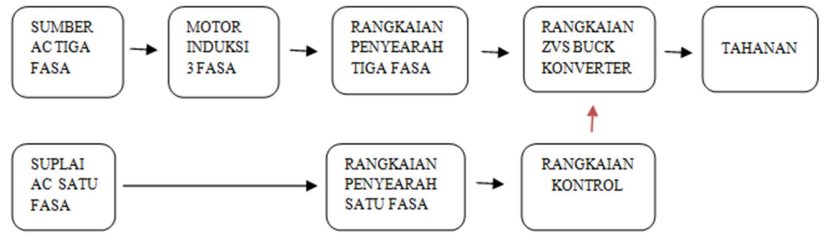

Ket :

$\rightarrow$ : aliran sinyal

$\rightarrow$ : aliran daya

\section{A. Perancangan zvs dengan motor induksi tiga fasa}

Perancangan simulasi di software PSIM digunakan untuk mengetahui karakteristik dan respon modul yang akan dibuat.

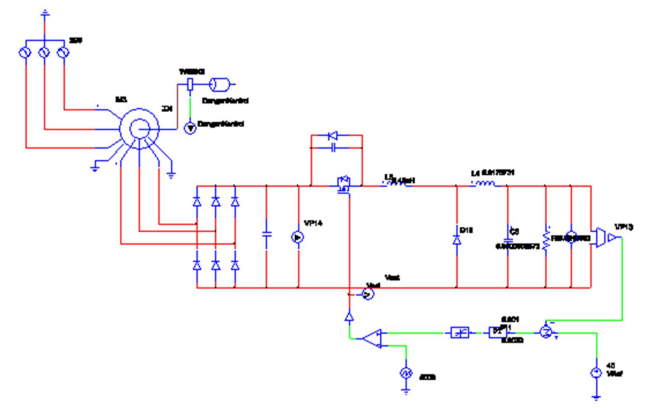

Gbr. A Zvs dengan motor induksi tiga fasa.

\section{B. Motor induksi rotor belit tiga fasa}

Motor induksi tiga fasa yang digunakan adalah motor induksi tiga fasa rotor lilit.

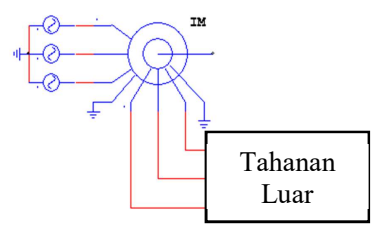

Gbr B. Motor Induksi tiga fasa

Tabel 1. Spesifikasi Motor Induksi Tiga Fasa Rotor Lilit

\begin{tabular}{|l|l|}
\hline Parameter & Spesifikasi/Nilai Besaran \\
\hline Name & Motor Induksi Tiga Fasa \\
\hline Rs (stator) & 0.294 \\
\hline $\mathrm{Ls}$ (stator) & $1.39 \mathrm{~m}$ \\
\hline $\mathrm{Rr}$ (stator) & 0.156 \\
\hline $\mathrm{Lr}$ (rotor) & $0.74 \mathrm{~m}$ \\
\hline $\mathrm{Lm}$ (magnetizing) & $41 \mathrm{~m}$ \\
\hline Ns/Nr Turns Ratio & 1 \\
\hline No. Of Poles P & 4 \\
\hline Moment of inertia & 0.4 \\
\hline Torque Flag & 0 \\
\hline Master/Slave Flag & 1 \\
\hline
\end{tabular}




\section{Rangkaian penyearah tiga fasa}

Rangkaian ini berfungsi mensuplai tegangan dari rotor ke rangkaian DC konverter. Tegangan sumber $220 \mathrm{AC}$ diturunkan dan didapat dari penyearahan tegangan AC 25 Volt sehingga menjadi tegangan DC 35 Volt .

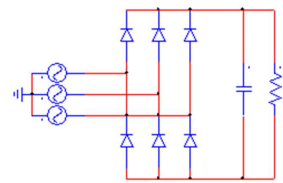

Gbr C. Rangkaian Penyearah Tiga Fasa

\section{ZVS buck konverter}

proses pensaklaran terjadi pada kondisi arus nol dan pada tipe pensaklaran ZVS, proses pensaklaran terjadi pada kondisi tegangan nol.

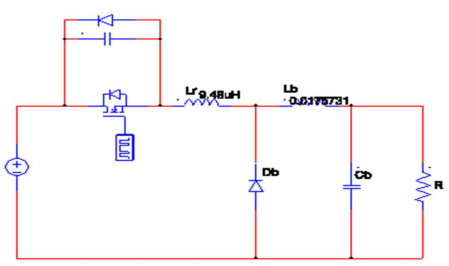

Gbrr D. ZVS buck converter

Frekuensi pensaklaran dan frekuensi resonansi ditentukan berdasarkan Persamaan 1 berikut :

$$
\mathrm{f}_{0} \geq \mathrm{f}_{\mathrm{s}}
$$

Pada penelitian ini frekuensi pensaklaran (fs) yang diinginkan adalah sebesar $15 \mathrm{kHz}-45 \mathrm{kHz}$, dan ditetapkan frekuensi resonansi (f0) sebesar $25 \mathrm{kHz}$.

1. Menentukan duty cycle buck

$$
\mathrm{Vo}=\mathrm{k} . \mathrm{vs}
$$

$$
\begin{aligned}
& \text { Vo }=\text { Tegangan output } \\
& \text { Vs }=\text { Tegangan input } \\
& \mathrm{k}=\text { Duty cycle }
\end{aligned}
$$

2. Menentukan Resistor $(R)$

$$
\mathrm{R}=\mathrm{Vo} / \mathrm{Io}
$$

3. Menentukan Capasitor (C)

$$
\mathrm{C}=(\mathrm{k} . \mathrm{V} \mathrm{s}+\Delta \mathrm{V})((1-\mathrm{k})) / \mathrm{fR} \Delta \mathrm{V}
$$

$\mathrm{f}=$ frekuensi

$\mathrm{R}=$ Resistor

\section{E. Pengendali PI}

Dalam pengendali PI terdapat beberapa parameter yang harus diatur untuk mendapatkan respon keluaran yang lebih baik. Parameter parameter yang dimaksud adalah parameter proportional $(\mathrm{Kp})$, integral (1/s K1). Beberapa parameter di atas memiliki fungsi dan kelebihan masing-masing untuk mengontrol suatu plant. Parameter proportional $(\mathrm{Kp})$ berfungsi untuk mengurangi rise time dan steady state error. Parameter integral berfungsi untuk menghilangkan steady state error pada suatu plant. Jika kedua pengendali di atas $\mathrm{P}$ dan I digabung maka akan menghasilkan pengendali PI.

\section{HASIL DAN PEMBAHASAN}

Simulasi ZVS buck converter dengan menggunakan control loop tertutup yang di lakukan pada paper ini bertujuan untuk menganalisa eror study state respon time, dengan memberikan kontrol kecepatan yang berbeda-beda

A. Analisa hasil tanpa beban

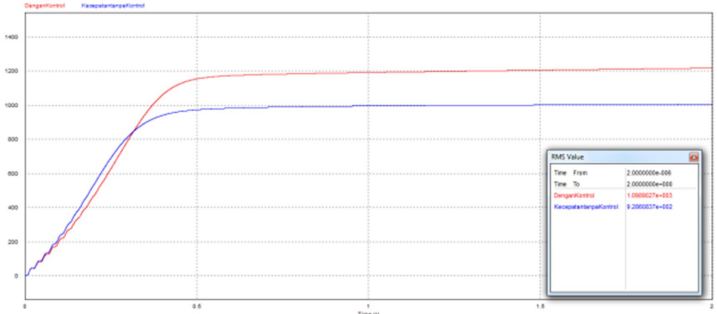

Gbr A hasil kontrol kecepatan tanpa beban

Dengan adanya perbandingan antara rangkaian buck converter, maka di buktikan dengan adanya hasil grafik di atas dimana untuk warna merah terkontrol dan warna biru tidak terkontrol.

\begin{tabular}{|c|c|c|c|c|}
\hline & Kecepatan & Eror & $\begin{array}{c}\text { Respon } \\
\text { time }\end{array}$ & Overshoot \\
\hline $\begin{array}{c}\text { Tanpa } \\
\text { kontrol }\end{array}$ & 985 & - & 0.65 & 1004 \\
\hline
\end{tabular}

Tabel A. kontrol kecepatan tanpa beban

B. Analisa hasil dengan beban $0.1 \mathrm{Nm}$

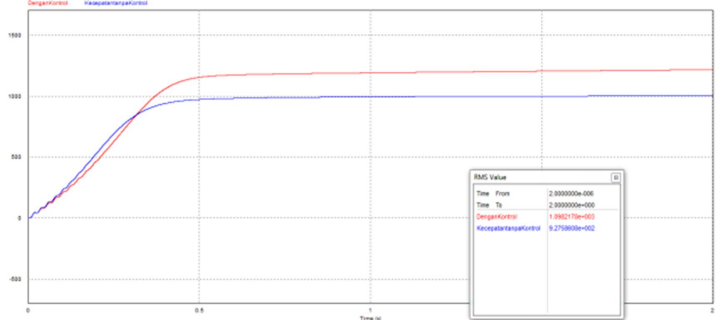

Gbr B. hasil kontrol kecepatan dengan beban $1 \mathrm{Nm}$

Penjelasan dari grafik ini sama dengan perbedaan pada pengaruh adanya beban, aapun parameter dari kecepatan $=990$, respon time $=0.62$, Eror study state $=2.1 \%$, Beban $=0.1 \mathrm{Nm}$, overshoot $=1003$

\begin{tabular}{|c|c|c|c|c|}
\hline & Kecepatan & Eror & $\begin{array}{c}\text { Respon } \\
\text { time }\end{array}$ & Overshoot \\
\hline $\begin{array}{c}\text { Tanpa } \\
\text { kontrol }\end{array}$ & 990 & - & 0.65 & 1003 \\
\hline $\begin{array}{c}\text { Dengan } \\
\text { kontrol }\end{array}$ & 1180 & $2.1 \%$ & 0.62 & - \\
\hline
\end{tabular}

Tabel B. kontrol kecepatan dengan beban $0.1 \mathrm{Nm}$

C. Analisa hasil dengan beban $0.2 \mathrm{Nm}$

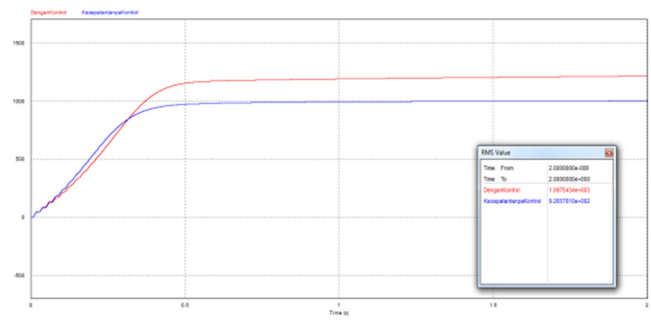

Gbr C kontrol kecepatan dengan beban $0.2 \mathrm{Nm}$ 
Penjelasan dari grafik sama dengan gambar 4 dan 5 . Perbedaan terletak pada pengaruh adanya beban, adapun parameter dari kecepatan $=1160$, respon time $=0.69$, Error stedy state $=2.7 \%$ Beban $=0.2 \mathrm{Nm}$, Overshoot $=1001$.

\begin{tabular}{|c|c|c|c|c|}
\hline & Kecepatan & Eror & $\begin{array}{c}\text { Respon } \\
\text { time }\end{array}$ & Overshoot \\
\hline $\begin{array}{c}\text { Tanpa } \\
\text { kontrol }\end{array}$ & 990 & - & 0.69 & 1001 \\
\hline $\begin{array}{c}\text { Dengan } \\
\text { kontrol }\end{array}$ & 1160 & $2.7 \%$ & 0.69 & - \\
\hline
\end{tabular}

Tabel C kontrol kecepatan dengan beban $0.2 \mathrm{Nm}$

\section{KESIMPULAN}

Berdasarkan hasil simulasi dari paper ini dapat disimpulkan pengaturan kecepatan motor dengan menghubungkan resistor luar tiga fasa pada slip ring rotornya.Hasil pengukuran pengaturan arus rotor pada motor induksi tiga fasa dengan metode ZVS dapat merubah kecepatan rotor pada motor induksi tiga fasa pada rotor lilit terserbut. kecepatan yang dihasilkan sesuai dengan pemasangan variable resistor tiga fase. Pengaturan variabel resistor dilakukan secara mekanik untuk mengubah kecepatan motor. Untuk memudahkan pengaturan kecepatan motor, digunakan rangkaian arus searah yang hanya membutuhkan satu tahanan luar.

\section{DAFTAR PUSTAKA}

[1] M. K. Kazimierczuk, Pulse-width Modulated DC - DC Power Converters, 3rd ed. Ohio: John Wiley \& Sons Ltd, 2008.J. Clerk Maxwell, A Treatise on Electricity and Magnetism, 3rd ed., vol. 2. Oxford: Clarendon, 1892, pp.68-73.

[2] Lendyanto Reza, Sukmadi, Windarta. Pengaruh Pengaturan Boost Converter terhadap torsi dan kecepatan motor induksi tiga fasa rotot belitan, 2017.K. Elissa, "Title of paper if known," unpublished.

[3] S. J. Chapman, Electric Machinaery Fundamentals, 4th ed. Australia: McGraw-Hill Companies, 2003.

[4] Andreycak, Bill. Zero Voltage Switching Resonant Power Conversion. Texas Instruments Inc. United States. 1999.

[5] Rahman Zya, Windarta dan Hermawan. Perancangan Zero Voltage Switching Buck dengan beban resistif bervariasi dan sebagai catu daya untuk motor arus searah. 2018.

[6] Gunawan. Rancang Bangun DC-DC Buck Converter dengan PID Diskrit sebagai Pengendali Tegangan Keluaran. UI, 2009.

[7] Jamlay Marselin, Faizal. Dual Feedback control Boost Converter menggunakan PI Controller. 2014.

[8] Ashari, Mochamad. Sistem Konverter DC"ITS Pers, Surabaya 2012 W.E Robert "Fundamentals Power Electronics" Cluwer Academic Publisshers, New York. 2001. 